\title{
Respective effects of phlebotomy losses and erythropoietin treatment on the need for blood transfusion in very premature infants
}

Odile Becquet ${ }^{1}$, Delphine Guyot ${ }^{2}$, Philippe Kuo ${ }^{2}$, Françoise Pawlotsky ${ }^{2}$, Marianne Besnard ${ }^{2}$, Micheline Papouin $^{2}$ and Alexandre Lapillonne $e^{1,3^{*}}$

\begin{abstract}
Background: The benefit to risk ratio of the treatment with erythropoietin (EPO) as a means of limiting the number of transfusions in very preterm infants during hospitalization, seems to be modest since the adoption of restrictive transfusion criteria and of policy limiting phlebotomy losses. We therefore aim to evaluate the factors associated with the number of late blood transfusion in very preterm infants in a unit where the routine use of EPO has been discontinued.

Methods: A comparative "before-after" study was carried out in premature infants born before 32 weeks postmenstrual age (PMA), over a period of one year before (EPO group) and one year after (non-EPO group) the discontinuation of EPO therapy.

Results: A total of 48 infants were included in the study $(E P O=21$; non- $E P O=27)$. The number of infants transfused after the 15 day of life (D15) and the number of transfusions per infant after D15 were not significantly different between the two groups. In a multivariate analysis, the gestational age and the volume of blood drawn off during the first month of life significantly influenced the need for transfusions after the 15th day of life, independently of the treatment with EPO. The hemoglobin levels measured at different times of hospitalization (median postnatal age: 16, 33 and 67 days) were not significantly different between the two groups.

Conclusions: Our study shows that the discontinuation of EPO did not change the number of late transfusions. Even when a policy limiting phlebotomy losses is used, blood loss is an important and independent risk factor for late transfusion of very preterm infants.
\end{abstract}

Keywords: Erythropoietin, Anemia of prematurity, Erythrocyte transfusion, Blood loss

\section{Background}

The anemia of premature infants is more severe and more prolonged than of term neonates. Below a certain threshold, this anemia becomes pathologic as it no longer permits a tissue oxygenation adequate for growth and development, and then, a blood transfusion is required. Since infants born prematurely display low erythropoietin (EPO) plasma levels and a retarded increase in its secretion, the use of recombinant EPO to limit the number of transfusions in premature infants has been proposed since

\footnotetext{
* Correspondence: alexandre.lapillonne@nck.aphp.fr

'Department of Neonatology, APHP Necker Hospital, Paris, France

${ }^{3}$ Paris Descartes University, Paris, France

Full list of author information is available at the end of the article
}

a pilot study published in the 90's [1]. The controlled randomized trials which were then published showed that the use of EPO in premature neonates significantly reduces the number of transfusions and the volume of blood transfused [2-6]. These studies also highlighted the facts that very broad and liberal transfusion criteria were used [3] and that the quantities of blood drawn off could be responsible of important blood losses [7]. The studies published since 2000 indicate that the effects of EPO treatment on the requirement for blood transfusions are moderate if more strict transfusion criteria and policy to limit phlebotomy losses are applied [8-12]. Furthermore, they showed that EPO does not reduce the need for 
transfusion within the first 15 days of life $[13,14]$ on account of the delayed action of the hormone [15].

In 2006, the Cochrane collaboration published three meta-analyses $[14,16,17]$. The first showed that administration of EPO from the 8th day of life afforded a reduction in the volume of blood transfused of $7 \mathrm{~mL} / \mathrm{kg} /$ infant and a diminution of 0.78 transfusions per infant. Conversely, the use of EPO did not diminish the risk of transfusion as there was no significant reduction in the number of donors [16]. The second indicated that EPO therapy started within the first 7 days of life permitted a decrease in the volume of blood transfused of $6 \mathrm{~mL} / \mathrm{kg} /$ infant, a diminution of 0.33 transfusions per infant and a significant decrease in the number of donors. This study revealed, on the other hand, a significant increase in the incidence of retinopathy of stage $\geq 3$ [17]. Finally, the third meta-analysis showed that the number of transfusions and the volume of blood transfused were similar whether EPO was administered early (before 8 th day of life) or late [14]. Since these successive analyses, more strict transfusion criteria have been progressively adopted by neonatal intensive care units (NICUs) in France and other countries, and the indications for treatment with EPO have been progressively restricted [18].

For about 10 years, we have implemented in our NICU a policy of conservative blood management, and a protocol including strict blood transfusion criteria. In view of the above data showing a modest impact of EPO treatment on transfusion requirements, together with the potentially severe side effects [19] and the fact that the procedure is painful for the infant [20], it was decided in our neonatology unit to suspend EPO therapy in premature newborns as of 1st August 2010. The objective of the present study was to evaluate the effects of this policy change on late transfusion requirements (i.e., after 15 days of life; $(\geq \mathrm{D} 15))$ and on the evolution of hemoglobin levels during hospitalization.

\section{Methods}

\section{Study design}

A "before-after" study was carried out in the NICU of the Territorial Hospital Center of French Polynesia during two consecutive years before and after the discontinuation of EPO therapy: from $01 / 08 / 2009$ to $31 / 07 / 2010$, i.e., one year before the arrest of EPO treatment (treated group) and from $01 / 08 / 2010$ to $31 / 07 / 2011$, i.e., one year after the arrest of treatment (non-treated group). The data were retrieved from the medical records.

\section{Inclusion and exclusion criteria}

All premature infants born at a postmenstrual age (PMA) < 32 weeks and a birth weight $\leq 1500 \mathrm{~g}$ during the study periods were included. The exclusion criteria were infants suffering from a congenital malformation or a hemolytic disease (i.e., blood group incompatibilities and G6PD or pyruvate kinase deficiencies), and those who had required surgery.

\section{Patient care protocols}

The infants belonging to the treated group received EPO (Epoetin beta, NeoRecormon ${ }^{\circ}$, ROCHE, France) from the first week of life (1st injection between D3 and D7), at a dose of $250 \mathrm{IU} / \mathrm{kg}$ three times a week subcutaneously for 6 weeks, i.e., a total of 18 injections.

The service has a policy of conservative blood management and a single donor for a given patient. Blood samples were drawn into tubes clearly indicating the quantity of blood necessary or were capillary samples. The quantity of blood required for blood cultures $(0.5 \mathrm{~mL})$ was measured in a syringe before being injected into the blood culture flask. Samples were analyzed by micro-methods and these methods were not modified between the two periods of the study. The samples were transferred rapidly to the laboratory by means of a pneumatic tube system. A limited number of physicians were responsible for the prescription of biological tests: the clinician in charge of the unit and the duty doctor. Particular attention was paid to the frequency and grouping of the blood tests. Finally, the unit protocol includes giving back the blood drawn on an umbilical line before the actual blood sample is obtained.

Enteral feeding was introduced progressively and as a function of the digestive tolerance. All infants were fed with pasteurized human milk until they reach 32 weeks corrected age, and then fed with either mother's milk enriched with a fortifier (Eoprotine ${ }^{\circ}$, MILUMEL, France) at a final concentration of $3 \%$ or a preterm formula (Pregallia, DANONE, France). The feeding protocol was not modified between the two periods of the study.

All the infants received an enteral iron supplement after the 7th day of life as soon as the total enteral intake reached $\geq 100 \mathrm{~mL} / \mathrm{kg} / \mathrm{d}$. The initial dose was $1.4 \mathrm{mg} / \mathrm{kg} / \mathrm{d}$ and was increased stepwise by $1.4 \mathrm{mg} / \mathrm{kg} / \mathrm{d}$ every $48 \mathrm{~h}$, according to the digestive tolerance, up to a target dose of 6.8 $\mathrm{mg} / \mathrm{kg} / \mathrm{d}$ (Sodium feredetate, Ferrostrane ${ }^{\circ}$ TEOFARMA, Italy). All the infants of the study were likewise given a folic acid supplement for one month, at a dose of $1.25 \mathrm{mg} / \mathrm{d}$ orally, as soon as the enteral intake exceeded $100 \mathrm{~mL} / \mathrm{kg} / \mathrm{d}$. The protocol for iron and folic acid supplementation underwent no modifications between the two periods of the study.

The indications for transfusion were the following protocol throughout the 2 study periods: 1 ) hemoglobin $<12 \mathrm{~g} / \mathrm{dL}$ if the infant was less than $48 \mathrm{~h}$ old, required respiratory support with $\mathrm{FiO} 2 \geq 40 \%$ or presented pulmonary arterial hypertension; 2) hemoglobin $<9 \mathrm{~g} / \mathrm{dL}$ in the case of respiratory support with Fi0 $<40 \%$, poor weight gain, episodes of hypoventilation, severe associated pathology 
or surgery; 3 ) hemoglobin $<8 \mathrm{~g} / \mathrm{dL}$ in other cases. The volume of blood delivered in each transfusion was $15 \mathrm{~mL} / \mathrm{kg}$.

\section{Data collection}

The epidemiological, clinical and biological data for each infant included were recovered from the medical records by one person (O.B.). Intrauterine growth retardation (IUGR) was defined as a birth weight of less than the 10th percentile for the gestational age on reference curves [21]. The achievement of respiratory autonomy was defined as spontaneous respiration in ambient air without tracheal or nasal support. Postnatal steroid therapy was defined as systemic therapy targeting the lungs and administered $\geq 15$ days of life. Severe cerebral lesions were defined as intraventricular hemorrhage (IVH) of a grade $\geq 3$ of the Papile classification [22] or as cystic periventricular leukomalacia. The presence of retinopathy of any stage, of a nosocomial infection suspected or confirmed by clinical, biological or bacteriological data, or of necrotizing enterocolitis of stage $\geq 3$ of the Bell classification was likewise retrieved.

Hemoglobin levels were measured at different times of hospitalization: during the first 24 hours of life $(\mathrm{Hb}$ at day 0 ), between the 14th and 21 st days of life ( $\mathrm{Hb}$ at 2 to $3 \mathrm{wks}$ ), between the 28th and 42nd days of life ( $\mathrm{Hb}$ at $1 \mathrm{mo}$ ) and between the 6th week of life and discharge from hospital or at the death of the infant ( $\mathrm{Hb}$ at discharge). The theoretical volume of blood drawn off for biological tests during the first 30 days of life was noted and recorded as a function of the birth weight.

The number of infants transfused and the number of transfusions per infant were retrieved for the period from the day of birth to discharge from hospital or death. Owing to the geographic situation of the hospital, no secondary transfers were performed. Transfusions were categorized as early when they took place $<15$ days of life and late $\geq 15$ days of life.

\section{Ethical information}

This study was conducted according to the guidelines of the Declaration of Helsinki. According to French legislation, neither ethical approval nor informed consent was required for this non-interventional, retrospective cohort study.

\section{Statistical analyses}

Statistical analyses were performed using Minitab $13.3^{\circ}$ software (Minitab Inc., Pennsylvania, USA). Qualitative variables were expressed as percentages and quantitative variables as medians and extremes. The variables "gestational age at birth" and "birth weight" were divided into the following classes: <28 weeks, 28-29.9 weeks and 30-32 weeks for the gestational age and $<1000 \mathrm{~g}$ and $\geq 1000 \mathrm{~g}$ for the birth weight. Discontinuous data were compared with the Fisher exact test and continuous data with the
Mann-Whitney U test. To determine the factors that affect the need for transfusion after the 15th day of life, the factors presenting a degree of significance of $\mathrm{p} \leq 0.1$ in the univariate analysis (i.e., intrauterine growth retardation, gender, gestational age) were included in a binary logistic regression model together with the volume of phlebotomy losses and the treatment with EPO. The relations between these factors were expressed as odds ratio with a $95 \%$ confidence interval. Tests were considered to be significant for a $\mathrm{p}$ value of less than 0.05 .

\section{Results}

\section{Description of the study groups}

All eligible infants $(n=48)$ were included in the study: 21 in the treated group and 27 in the non-treated group. None were excluded because of postnatal transfer since the unit is geographically very far from any other level II ou level III units (i.e., no other neonatal unit in the island of Tahiti). The clinical characteristics of the children are presented in Table 1. The two groups were comparable for all criteria except gender $(p=0.01)$, the incidence of IUGR $(\mathrm{p}=0.04)$ and severe neurological lesions $(\mathrm{p}=0.02)$. Two children died during the study on D43 and D54 respectively; both belonged to the treated group. The hemoglobin at birth, the number of early transfusions and the volume of blood drawn off during the first month of life were comparable (Table 2).

\section{Effects of the EPO treatment}

The number of infants transfused after D15 was identical in the two groups (Table 2). The number of transfusions per infant after D15 (mean \pm SD $=0.5 \pm 0.9$ in the treated group and $0.4 \pm 0.6$ in the non-treated group) was not significantly different nor was the volume of blood transfusion of the transfused infants (mean $\pm \mathrm{SD}=23.6 \pm$ $11.8 \mathrm{~mL} / \mathrm{kg}$ in the treated group and $18.3 \pm 6.6 \mathrm{~mL} / \mathrm{kg}$ in the non-treated group).

In the binary logistic regression model, only the variables "gestational age" and "volume of phlebotomy losses" were significantly and independently associated with the need for transfusion after 15 days of life, whereas treatment with EPO was not significant (Table 3). The levels of hemoglobin at different times of hospitalization were not significantly different between the two groups (Table 2).

\section{Discussion}

Our study shows that the discontinuation of EPO therapy did not significantly modify the number of infants transfused, the number of transfusions per infant after D15 or the hemoglobin levels after the 15th day of life in infants born very preterm. These results are concordant with those of the literature, which indicate that the clinical effects of EPO are limited or absent when restrictive transfusion criteria are employed $[8,9,12,23,24]$. Our work also confirms 
Table 1 Clinical characteristics of the newborns included in the study

\begin{tabular}{|c|c|c|c|c|}
\hline & Treated group $(n=21)$ & Non treated group $(n=27)$ & Total $(n=48)$ & $\mathbf{p}$ \\
\hline \multicolumn{5}{|l|}{ Gender* } \\
\hline boy & $14(67 \%)$ & $8(30 \%)$ & $22(46 \%)$ & 0.01 \\
\hline Gestationnal age (week) ** & $28.1[26.1-31.8]$ & $29.3[25.6-31.8]$ & $28.6[25.6-31.8]$ & 0.1 \\
\hline Birth weight (g) & $1100[802-1428]$ & 1110 [666- 1496] & 1105 [666- 1496] & 0.7 \\
\hline Birth length $(\mathrm{cm})$ & $36.5[30.0-40.8]$ & $37[31-43]$ & $37[30-43]$ & 0.3 \\
\hline Birth head circumference $(\mathrm{cm})$ & $26.5[22.0-29.5]$ & $26[22.5-28.5]$ & $26[22-29.5]$ & 0.4 \\
\hline Birth weight $<1000 \mathrm{~g}$ & $7(33 \%)$ & $8(30 \%)$ & $15(31 \%)$ & 0.8 \\
\hline Intrauterine growth retardation & $3(14 \%)$ & $11(40 \%)$ & $14(29 \%)$ & 0.04 \\
\hline \multicolumn{5}{|l|}{ Apgar score } \\
\hline $1 \mathrm{mn}$ & $7[2-10]$ & $6[3-10]$ & $6.5[2-10]$ & 0.3 \\
\hline $5 \mathrm{mn}$ & $9[5-10]$ & $9[7-10]$ & $9[5-10]$ & 0.3 \\
\hline $10 \mathrm{mn}$ & $10[8-10]$ & $10[8-10]$ & $10[8-10]$ & 0.9 \\
\hline Duration of hospitalization (d) & $67[40-102]$ & $63.5[37-96]$ & $65[37-102]$ & 0.3 \\
\hline Respiratory autonomy (d) & $40[4-94]$ & $37[0-88]$ & $37.5[0-94]$ & 0.2 \\
\hline Severe cerebral lesions & $4(19 \%)$ & $0(0 \%)$ & $4(8 \%)$ & 0.02 \\
\hline Post natal steroid therapy & $3(14 \%)$ & $3(11 \%)$ & $6(12 \%)$ & 0.7 \\
\hline Retinopathy & $2(9 \%)$ & $3(11 \%)$ & $5(10 \%)$ & 0.8 \\
\hline Nosocomial infection & $10(48 \%)$ & $6(22 \%)$ & 16 (33%) & 0.06 \\
\hline Necrotizing enterocolitis & $3(14 \%)$ & $2(7 \%)$ & $5(10.4)$ & 0.4 \\
\hline
\end{tabular}

Table 2 Hematological data of the newborns with and without erythropoietin therapy

\begin{tabular}{|c|c|c|c|c|}
\hline & Treated group $(n=21)$ & Non treated group $(n=27)$ & Total $(n=48)$ & $\mathbf{p}$ \\
\hline Volume of phlebotomy losses $(\mathrm{ml} / \mathrm{kg})^{*}$ & $16.8[6.9-49.4]$ & $14.5[7.6-50.0]$ & $15.1[6.9-50.0]$ & 0.7 \\
\hline Start of iron supplementation (age in days) & $22[13-51]$ & $20[5-38]$ & $20.5[5-51]$ & 0.5 \\
\hline \multicolumn{5}{|l|}{ Transfusions before day 15 of life } \\
\hline $\mathrm{Nb}$ of infants transfused $<\mathrm{D} 15^{* *}$ & $9(43 \%)$ & $5(18 \%)$ & $14(29 \%)$ & 0.07 \\
\hline Transfusions per infant <D15 & $0[0-2]$ & $0[0-1]$ & $0[0-2]$ & 0.9 \\
\hline \multicolumn{5}{|l|}{ Transfusion after day 15 of life } \\
\hline $\mathrm{Nb}$ of infants transfused $\geq \mathrm{D} 15$ & 7 (33\%) & $9(33 \%)$ & $16(33 \%)$ & 1.00 \\
\hline Transfusions per infant $\geq$ D15 & $0[0-3]$ & $0[0-2]$ & $0[0-3]$ & 0.6 \\
\hline \multicolumn{5}{|l|}{ Day 0 of life } \\
\hline Haemoglobin (g/dL) & $15.2[11.9-17.7]$ & $15.9[13.1-18.9]$ & 15.5 [11.9-18.9] & 0.2 \\
\hline \multicolumn{5}{|l|}{$2-3$ wks } \\
\hline Haemoglobin (g/dl) & $11.4[8.1-14.8]$ & $11.3[6.7-12.9]$ & $11[6.7-14.8]$ & 0.9 \\
\hline Age at sampling (d) & $15[14-21]$ & $16[14-21]$ & $16[14-21]$ & 0.3 \\
\hline \multicolumn{5}{|l|}{1 month of life } \\
\hline Haemoglobin (g/dl) & $9.9[8.4-12.8]$ & $10.0[8.1-12.9]$ & 10 [8.1 - 12.9] & 0.7 \\
\hline Age at sampling $(d)$ & 34 [29- 39] & $32[28-39]$ & $33[28-39]$ & 0.4 \\
\hline \multicolumn{5}{|l|}{ Discharge } \\
\hline \multirow[t]{2}{*}{ Haemoglobin (g/dl) } & $10.4[7.7-12.4]$ & 9.6 [8.4- 11.7] & $9.6[7.7-12.4]$ & 0.3 \\
\hline & $n=13$ & $n=21$ & $n=34$ & \\
\hline Age at sampling (d) & 72 [43 - 99] & $65[46-93]$ & $67[43-99]$ & 0.9 \\
\hline
\end{tabular}

${ }^{*}$ median [Min-Max], ${ }^{* *} \mathrm{n}(\%)$. 
Table 3 Influence of different factors on the need for transfusion after 15 days of life

\begin{tabular}{lccc}
\hline Variables & Odds ratio & $\mathbf{9 5 \%}$ IC & $\mathbf{p}$ \\
\hline Gestational age at birth* & 0.18 & $0.03-0.96$ & 0.044 \\
Intrauterine growth retardation & 0.63 & $0.06-6.94$ & 0.704 \\
Gender (boy) & 0.22 & $0.03-1.92$ & 0.171 \\
Volume of phlebotomy losses (mL/kg/d) & 1.17 & $1.01-1.36$ & 0.032 \\
Treatment with erythropoietin & 0.15 & $0.01-1.60$ & 0.118 \\
\hline
\end{tabular}

*The variable "gestational age at birth" was divided into the following classes: $<28$ weeks, 28-29.9 weeks and 30-32 weeks.

that the use of restrictive transfusion criteria is effective to limit the number of infants transfused [2,3,5,12,13,24-30]. Based on the results of the literature, the French authorities issued guidelines questioning the need for EPO when policies of restrictive transfusion criteria and a single donor for repeated transfusions were applied [18].

Cell transfusion practices vary widely among practicing neonatologists throughout the world [31]. Some studies have shown that it is equally efficacious to employ a conservative transfusion protocol as to use early administration of EPO in premature infants of gestational age $<30$ weeks and/or birth weight $<1500 \mathrm{~g}$ [24]. Others have demonstrated an absence of any increase in mortality, duration of hospitalization or occurrence of severe cerebral lesions, apnea, retinopathy or bronchopulmonary dysplasia when a conservative transfusion policy was employed [23,24]. However, although most authors have a tendency to use a restrictive guidelines, the use of a restrictive or liberal guidelines for red blood cell transfusion in preterm infants, remain a controversial issue since their impact on the neurosensorial and neurocognitive development through infanthood and childhood is inconsistent [26,32-35].

Our study shows that the volume of phlebotomy losses is an independent factor significantly associated with the need for late transfusion. Previous study have shown that considerable phlebotomy losses are a risk factor associated with the need for early transfusion in very preterm infants. For example, it has been shown in infants not treated with $\mathrm{EPO}$, that the volume of blood losses during the first 7 days of life is a significant predictive factor for transfusion over the first 7 days of life [36]. In a randomized controlled trial testing a bedside blood analyzer, blood transfusions administered to extremely low birth weight infants were reduced by decreasing laboratory phlebotomy losses [37]. Our study adds to the literature by the fact that the volume of phlebotomy losses is associated with the need for late transfusion even if an effective blood sparing protocol is applied. Indeed, our blood saving protocol is one of the most efficient published to date since the volume of phlebotomy losses during the first month of life was $\sim 0.5$ $\mathrm{mL} / \mathrm{kg} / \mathrm{d}$ in the two groups, which is a figure lower than most of the values published (Table 4).

Our work presents several limitations. The retrospective nature of the data collection imposes the limits inherent to this type of study. However, the number of infants transfused, the number of transfusions per infant and the evolution of hemoglobin levels were unlikely to be affected by their retrospective retrieval due to the existence of a transfusion record in all the medical files and the electronic recording of all biological results. On the other hand, there is probably some uncertainty concerning the actual volume

Table 4 Comparison of the volumes of phlebotomy losses in preterm infants published in the literature

\begin{tabular}{|c|c|c|c|c|}
\hline References & Year of publication & Population studied & Number of infants & Estimated losses $(\mathrm{ml} / \mathrm{kg} / \mathrm{d})$ \\
\hline [5] & 1993 & $27-33 w k s$ & 24 & 0.6 \\
\hline [2] & 1993 & $<33$ wks & 51 & 0.4 \\
\hline [3] & 1994 & $750-1500 \mathrm{~g}$ & 241 & 0.7 \\
\hline [36] & 1997 & $\leq 1500 \mathrm{~g}$ & 47 & 3.3 \\
\hline [25] & 1999 & $\leq 32 \mathrm{wks}$ & 100 & 0.6 \\
\hline [26] & 2000 & $<32 \mathrm{SA}$ and $<1250 \mathrm{~g}$ & 114 & 0.9 \\
\hline \multirow[t]{2}{*}{ [12] } & 2001 & $<1000 \mathrm{~g}$ & 172 & 1.8 \\
\hline & & $1000-1250 \mathrm{~g}$ & & 0.8 \\
\hline [13] & 2002 & $<1000 \mathrm{~g}$ & 219 & 0.7 \\
\hline [37] & 2005 & $500-1000 \mathrm{~g}$ & 93 & 5 \\
\hline [27] & 2006 & $450-800 \mathrm{~g}$ & 40 & 0.6 \\
\hline [24] & 2006 & $<30$ wks or $>1500 \mathrm{~g}$ & 50 & 2 \\
\hline [28] & 2008 & $1000-1750 \mathrm{~g}$ and $28-34 \mathrm{wks}$ & 40 & 0.8 \\
\hline [29] & 2011 & $\leq 1250 \mathrm{~g}$ and $<30 \mathrm{wks}$ & 30 & 0.4 \\
\hline [6] & 2013 & $500-1250 g$ & 99 & 0.8 \\
\hline Present study & & $<32$ weeks and $<1500 \mathrm{~g}$ & 47 & 0.5 \\
\hline
\end{tabular}


of blood drawn off and this could be underestimated [7], although it is unlikely that the error induced would be different between the two groups since the sampling procedure did not change during the period of the study. We could not assess the impact of the discontinuation of EPO therapy on reticulocytosis as the number of infants in whom this test was performed was too low, even though it is recognized that this parameter is affected by EPO $[9,38]$. The small number of patients in each group is a weakness of the study and makes the demonstration of the direct effect of the intervention (arrest of EPO) more uncertain. We could nevertheless calculate that the number of children included in the study allowed one to test the hypothesis of a doubling of the risk of transfusion with a power of $80 \%$ and an alpha risk of 0.05 . Our work shows that a gestational age of $<28$ weeks is an independent risk factor for late transfusions and hence it would be appropriate to specifically test the effects of EPO in this subgroup of extremely premature infants. Finally, our study was not able to determine the role of delayed cord clamping on the need for late blood transfusion since the procedure was not used in our perinatal department during the study periods.

\section{Conclusion}

In conclusion, this study showed that the number of late transfusions had not increased significantly one year after the discontinuation of EPO. In units where policies of conservative transfusion and single donors are applied, it would seem reasonable to discontinue the use of early EPO treatment for very preterm infants for which the administration procedure is painful, the large scale clinical efficacy is modest and the absence of side effects does not appear to be fully established. In the area of conservative transfusion policy and blood sparing, we found that phlebotomy losses remained an important risk factor for late transfusion.

\section{Abbreviations}

EPO: Erythropoietin; D: Days; PMA: Postmenstrual age.

\section{Competing interests}

The authors have no competing interests to declare.

\section{Authors' contributions}

OB: Provided clinical and scientific along the project, in particular for definition of objectives, patient inclusion and non-inclusion criteria validation, patient recruitment, acquisition of data, interpretation of results, and choice of concepts to be measured; reviewed critically the manuscript; approved the final version of the manuscript. DG: Made substantial contributions to acquisition of data and interpretation of data; have been involved in revising the manuscript critically for important intellectual content; and have given final approval of the version to be published. PK: Made substantial contributions to acquisition of data and interpretation of data; have been involved in revising the manuscript critically for important intellectual content; and have given final approval of the version to be published. FP: Made substantial contributions to acquisition of data and interpretation of data; have been involved in revising the manuscript critically for important intellectual content; and have given final approval of the version to be published. MB: Made substantial contributions to acquisition of data and interpretation of data; have been involved in revising the manuscript critically for important intellectual content; and have given final approval of the version to be published. MP: Made substantial contributions to acquisition of data and interpretation of data; have been involved in revising the manuscript critically for important intellectual content; and have given final approval of the version to be published. AL: Provided clinical and scientific expertise on EPO along the project, in particular for definition of objectives, patient inclusion and non-inclusion criteria validation, patient recruitment, interpretation of results, and choice of concepts to be measured; reviewed critically the manuscript; approved the final version of the manuscript. All authors read and approved the final manuscript.

\section{Acknowledgments}

The authors would like to thank Lydie Drouet for editorial work and the Association pour la Recherche et la Formation En Neonatologie (ARFEN) for providing technical assistance.

\section{Author details}

${ }^{1}$ Department of Neonatology, APHP Necker Hospital, Paris, France. ${ }^{2}$ Department of Neonatology, Territorial Hospital of Tahiti, Papeete, French Polynesia. ${ }^{3}$ Paris Descartes University, Paris, France.

Received: 30 April 2013 Accepted: 14 October 2013

Published: 28 October 2013

\section{References}

1. Halperin DS, Wacker P, Lacourt G, Felix M, Babel JF, Aapro M, Wyss M: Effects of recombinant human erythropoietin in infants with the anemia of prematurity: a pilot study. J Pediatr 1990, 116(5):779-786.

2. Messer J, Haddad J, Donato L, Astruc D, Matis J: Early treatment of premature infants with recombinant human erythropoietin. Pediatrics 1993, 92(4):519-523.

3. Maier RF, Obladen M, Scigalla P, Linderkamp O, Duc G, Hieronimi G, Halliday $H \mathrm{~L}$, Versmold HT, Moriette $\mathrm{G}$, Jorch $\mathrm{G}$, et al: The effect of epoetin beta (recombinant human erythropoietin) on the need for transfusion in very-low-birth-weight infants. European Multicentre Erythropoietin Study Group. The New England journal of medicine 1994, 330(17):1173-1178.

4. Soubasi V, Kremenopoulos G, Diamandi E, Tsantali C, Tsakiris D: In which neonates does early recombinant human erythropoietin treatment prevent anemia of prematurity? Results of a randomized, controlled study. Pediatr Res 1993, 34(5):675-679.

5. Emmerson AJ, Coles HJ, Stern CM, Pearson TC: Double blind trial of recombinant human erythropoietin in preterm infants. Arch Dis Child 1993, 68(3 Spec No):291-296.

6. Ohls RK, Christensen RD, Kamath-Rayne BD, Rosenberg A, Wiedmeier SE, Roohi M, Lacy CB, Lambert DK, Burnett JJ, Pruckler B, et al: A randomized, masked, placebo-controlled study of darbepoetin alfa in preterm infants. Pediatrics 2013, 132(1):e119-127.

7. Lin JC, Strauss RG, Kulhavy JC, Johnson KJ, Zimmerman MB, Cress GA, Connolly NW, Widness JA: Phlebotomy overdraw in the neonatal intensive care nursery. Pediatrics 2000, 106(2):E19.

8. Franz AR, Pohlandt F: Red blood cell transfusions in very and extremely low birthweight infants under restrictive transfusion guidelines: is exogenous erythropoietin necessary? Arch Dis Child Fetal Neonatal Ed 2001, 84(2):F96-F100

9. Strauss RG: Controversies in the management of the anemia of prematurity using single-donor red blood cell transfusions and/or recombinant human erythropoietin. Transfus Med Rev 2006, 20(1):34-44.

10. Bishara N, Ohls RK: Current controversies in the management of the anemia of prematurity. Semin Perinatol 2009, 33(1):29-34.

11. Vamvakas EC, Strauss RG: Meta-analysis of controlled clinical trials studying the efficacy of rHuEPO in reducing blood transfusions in the anemia of prematurity. Transfusion 2001, 41(3):406-415.

12. Ohls RK, Ehrenkranz RA, Wright LL, Lemons JA, Korones SB, Stoll BJ, Stark AR, Shankaran S, Donovan EF, Close NC, et al: Effects of early erythropoietin therapy on the transfusion requirements of preterm infants below 1250 grams birth weight: a multicenter, randomized, controlled trial. Pediatrics 2001, 108(4):934-942. 
13. Maier RF, Obladen M, Muller-Hansen I, Kattner E, Merz U, Arlettaz R, Groneck P, Hammer $H$, Kossel $H$, Verellen $G$, et al: Early treatment with erythropoietin beta ameliorates anemia and reduces transfusion requirements in infants with birth weights below $1000 \mathrm{~g}$. J Pediatr 2002, 141(1):8-15

14. Aher SM, Ohlsson A: Early versus late erythropoietin for preventing red blood cell transfusion in preterm and/or low birth weight infants. Cochrane Database Syst Rev 2006, 3, CD004865.

15. Freise KJ, Widness JA, Veng-Pedersen P: Erythropoietic response to endogenous erythropoietin in premature very low birth weight infants. J Pharmacol Exp Ther 2010, 332(1):229-237.

16. Aher S, Ohlsson A: Late erythropoietin for preventing red blood cell transfusion in preterm and/or low birth weight infants. Cochrane Database Syst Rev 2006, 3, CD004868.

17. Ohlsson A, Aher SM: Early erythropoietin for preventing red blood cell transfusion in preterm and/or low birth weight infants. Cochrane Database Syst Rev 2006, 3, CD004863.

18. AFSSAPS: Transfusion de Globules rouges homologues : produits, indications, alternatives. Methode générale, Recommandation. Transfus Clin Biol 2002, 9:33-56.

19. Aher SM, Ohlsson A: Early versus late erythropoietin for preventing red blood cell transfusion in preterm and/or low birth weight infants. Cochrane Database Syst Rev 2012, 10, CD004865.

20. Carbajal R, Lenclen R, Gajdos V, Jugie M, Paupe A: Crossover trial of analgesic efficacy of glucose and pacifier in very preterm neonates during subcutaneous injections. Pediatrics 2002, 110(2 Pt 1):389-393.

21. Beeby PJ, Bhutap T, Taylor LK: New South Wales population-based birthweight percentile charts. J Paediatr Child Health 1996, 32(6):512-518.

22. Papile LA, Burstein J, Burstein R, Koffler $H$ : Incidence and evolution of subependymal and intraventricular hemorrhage: a study of infants with birth weights less than 1,500 gm. J Pediatr 1978, 92(4):529-534.

23. Whyte $\mathrm{R}$, Kirpalani $\mathrm{H}$ : Low versus high haemoglobin concentration threshold for blood transfusion for preventing morbidity and mortality in very low birth weight infants. Cochrane Database Syst Rev 2011, 11, CD000512

24. Birenbaum HJ, Pane MA, Helou SM, Starr KP: Comparison of a restricted transfusion schedule with erythropoietin therapy versus a restricted transfusion schedule alone in very low birth weight premature infants. South Med J 2006, 99(10):1059-1062.

25. Trentesaux AS, Egreteau L, Santerne B, Morville P: Recombinant human erythropoietin in premature infants. Evaluation of a one year experience. Arch Pediatr 1999, 6(9):944-951.

26. Donato H, Vain N, Rendo P, Vivas N, Prudent L, Larguia M, Digregorio J, Vecchiarelli C, Valverde R, Garcia C, et al: Effect of early versus late administration of human recombinant erythropoietin on transfusion requirements in premature infants: results of a randomized, placebocontrolled, multicenter trial. Pediatrics 2000, 105(5):1066-1072.

27. Haiden N, Schwindt J, Cardona F, Berger A, Klebermass K, Wald M, Kohlhauser-Vollmuth C, Jilma B, Pollak A: Effects of a combined therapy of erythropoietin, iron, folate, and vitamin B12 on the transfusion requirements of extremely low birth weight infants. Pediatrics 2006, 118(5):2004-2013

28. Khatami SF, Mamouri G, Torkaman M: Effects of early human recombinant erythropoietin therapy on the transfusion in healthy preterm infants. Indian J Pediatr 2008, 75(12):1227-1230.

29. Tempera A, Stival E, Piastra M, De Luca D, Ottaviano C, Tramontozzi P, Marconi M, Cafforio C, Marcozzi P, Rossi N, et al: Early erythropoietin influences both transfusion and ventilation need in very low birth weight infants. J Matern Fetal Neonatal Med 2011, 24(8):1060-1064.

30. Ohlsson A, Aher SM: Early erythropoietin for preventing red blood cell transfusion in preterm and/or low birth weight infants. Cochrane Database Syst Rev 2012, 9, CD004863.

31. Guillen U, Cummings JJ, Bell EF, Hosono S, Frantz AR, Maier RF, Whyte RK, Boyle $E$, Vento $M$, Widness JA, et al: International survey of transfusion practices for extremely premature infants. Semin Perinatol 2012, 36(4):244-247.

32. Whyte RK, Kirpalani H, Asztalos EV, Andersen C, Blajchman M, Heddle N, LaCorte M, Robertson CM, Clarke MC, Vincer MJ, et al: Neurodevelopmental outcome of extremely low birth weight infants randomly assigned to restrictive or liberal hemoglobin thresholds for blood transfusion. Pediatrics 2009, 123(1):207-213.
33. Bell EF, Strauss RG, Widness JA, Mahoney LT, Mock DM, Seward VJ, Cress GA Johnson KJ, Kromer IJ, Zimmerman MB: Randomized trial of liberal versus restrictive guidelines for red blood cell transfusion in preterm infants. Pediatrics 2005, 115(6):1685-1691.

34. McCoy TE, Conrad AL, Richman LC, Lindgren SD, Nopoulos PC, Bell EF: Neurocognitive profiles of preterm infants randomly assigned to lower or higher hematocrit thresholds for transfusion. Child Neuropsychol 2011 17(4):347-367.

35. Nopoulos PC, Conrad AL, Bell EF, Strauss RG, Widness JA, Magnotta VA, Zimmerman MB, Georgieff MK, Lindgren SD, Richman LC: Long-term outcome of brain structure in premature infants: effects of liberal vs restricted red blood cell transfusions. Arch Pediatr Adolesc Med 2011, 165(5):443-450.

36. Kling PJ, Sullivan TM, Leftwich ME, Roe DJ: Score for neonatal acute physiology and phlebotomy blood loss predict erythrocyte transfusions in premature infants. Arch Pediatr Adolesc Med 1997, 151(1):27-31.

37. Widness JA, Madan A, Grindeanu LA, Zimmerman MB, Wong DK, Stevenson DK: Reduction in red blood cell transfusions among preterm infants: results of a randomized trial with an in-line blood gas and chemistry monitor. Pediatrics 2005, 115(5):1299-1306.

38. Shannon KM, Keith JF 3rd, Mentzer WC, Ehrenkranz RA, Brown MS, Widness JA, Gleason CA, Bifano EM, Millard DD, Davis CB, et al: Recombinant human erythropoietin stimulates erythropoiesis and reduces erythrocyte transfusions in very low birth weight preterm infants. Pediatrics 1995, 95(1):1-8.

\section{doi:10.1186/1471-2431-13-176}

Cite this article as: Becquet et al:: Respective effects of phlebotomy losses and erythropoietin treatment on the need for blood transfusion in very premature infants. BMC Pediatrics 2013 13:176.

\section{Submit your next manuscript to BioMed Central and take full advantage of:}

- Convenient online submission

- Thorough peer review

- No space constraints or color figure charges

- Immediate publication on acceptance

- Inclusion in PubMed, CAS, Scopus and Google Scholar

- Research which is freely available for redistribution 